Nat. Hazards Earth Syst. Sci., 18, 3203-3210, 2018

https://doi.org/10.5194/nhess-18-3203-2018

(C) Author(s) 2018. This work is distributed under

the Creative Commons Attribution 4.0 License.

\title{
Roads and landslides in Nepal: how development affects environmental risk
}

\author{
Brian G. McAdoo ${ }^{1}$, Michelle Quak ${ }^{1}$, Kaushal R. Gnyawali ${ }^{2}$, Basanta R. Adhikari ${ }^{3}$, Sanjaya Devkota ${ }^{3}$, \\ Purna Lal Rajbhandari ${ }^{4}$, and Karen Sudmeier-Rieux ${ }^{5}$ \\ ${ }^{1}$ Environmental Studies, Yale-NUS College, Singapore \\ ${ }^{2}$ Natural Hazards Section, Himalayan Risk Research Institute, Kathmandu, Nepal \\ ${ }^{3}$ Department of Civil Engineering, Tribhuvan University, Kathmandu, Nepal \\ ${ }^{4}$ Independent consultant, Kathmandu, Nepal \\ ${ }^{5}$ University of Lausanne, Faculty of Geosciences and Environment, Institute of Earth Science, Lausanne, Switzerland
}

Correspondence: Brian G. McAdoo (brian.mcadoo@yale-nus.edu.sg)

Received: 31 December 2017 - Discussion started: 22 January 2018

Revised: 2 November 2018 - Accepted: 9 November 2018 - Published: 30 November 2018

\begin{abstract}
The number of deaths from landslides in Nepal has been increasing dramatically due to a complex combination of earthquakes, climate change, and an explosion of informal road construction that destabilizes slopes during the rainy season. This trend will likely rise as development continues, especially as China's Belt and Road Initiative seeks to construct three major trunk roads through the Nepali Himalaya that adjacent communities will seek to tie in to with poorly constructed roads. To determine the effect of these informal roads on generating landslides, we compare the distance between roads and landslides triggered by the 2015 Gorkha earthquake with those triggered by monsoon rainfalls, as well as a set of randomly located landslides to determine if the spatial correlation is strong enough to further imply causation. If roads are indeed causing landslides, we should see a clustering of rainfall-triggered landslides closer to the roads that accumulate and focus the water that facilitates failure. We find that in addition to a concentration of landslides in landscapes with more developed, agriculturally viable soils, that the rainfall-triggered landslides are more than twice as likely to occur within $100 \mathrm{~m}$ of a road than the landslides generated by the earthquake. The oversteepened slopes, poor water drainage and debris management provide the necessary conditions for failure during heavy monsoonal rains. Based on these findings, geoscientists, planners and policymakers must consider how road development affects the physical (and ecological), socio-political and economic factors that
\end{abstract}

increase risk in exposed communities, alongside ecologically and financially sustainable solutions such as green roads.

\section{Introduction}

On 29 and 30 July 2015, during the first monsoon season after the $M_{\mathrm{w}}=7.8$ Gorkha earthquake, a dramatic cloudburst triggered landslides that killed 29 people in Nepal's western region (BBC, 2015). These deadly landslides and many others like them are not solely the result of intensified rainfall associated with climate change (Bharti et al., 2016), but a complex intersection of socio-economic factors with a highly altered physical landscape where informal, non-engineered roads regularly fail during the annual monsoon season (Petley et al., 2007; Froude and Petley, 2018). This problem will become more acute as China's Belt and Road Initiative (BRI) aims to expand trade into Nepal, India and beyond via a series of trans-Himalayan corridors which traverse some of the world's most geomorphically complex terrain (Bhushal, 2017). This expanded transportation network will have unintended effects on the surrounding landscapes as villages seek to link to these highways with informal roads constructed and maintained with severely limited resources, putting them more at risk of landsliding.

The problem of roads and associated landslides has been a long recognized yet understudied phenomenon. Laban (1979) provided an early quantification of the effects 


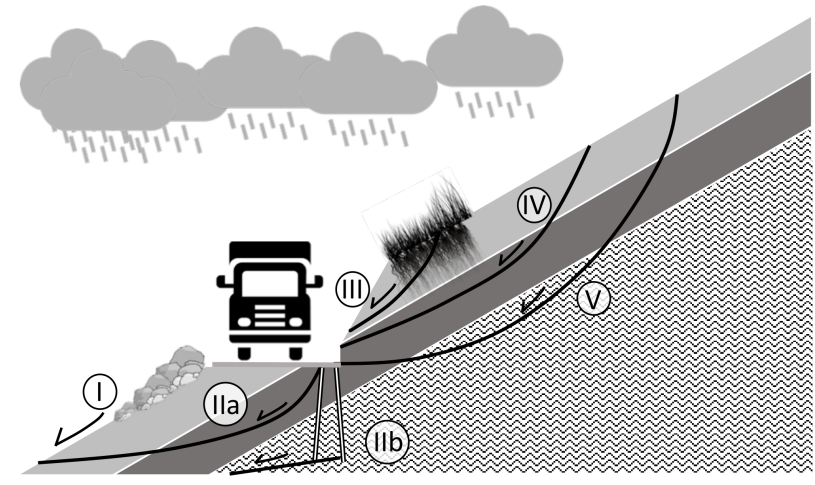

Figure 1. There are five primary modes of potentially damaging mass movements caused by informal road construction in Nepal - (I) debris flows from excavated material stored on the downslope side of the road; (II) deeper seated landslides that are accommodated by poor road drainage as water seepage can aid failures that include regolith (IIa), and freeze-thaw in joints that can result in bedrock failures (IIb); (III) shallow failures close to the road caused by oversteepened road cuts that may be mitigated by planting; (IV) shallow landslides caused by oversteepening that include potentially stabilizing roots from vegetation; (V) deeper seated failures triggered by oversteepening by road cuts that may include bedrock.

of human development on the distribution of landslides in Nepal, concluding that in the nascent days of Nepal's vehicular road development, only $5 \%$ of observed landslides were associated with roads. While road density data are not available from this time, the density more than tripled from $13.7 \mathrm{~km} \mathrm{~km}^{-2}$ in 1998 to $49.6 \mathrm{~km} \mathrm{~km}^{-2}$ in 2016 (DoR, 2002, 2017). Petley et al. (2007) show that number of landslide fatalities in Nepal increased dramatically 1978-2005 and expresses concern over poorly constructed roads. Despite this evidence of increasing losses, there have been a limited number of studies of roads and landslides in Nepal (Laban, 1979; Bhandary et al., 2013), and while the BRI indeed portends increases economic opportunity, it will also bring with it an expansion of this risky road network.

Many villages in the Middle Hills region of rural Nepal are connected by simple footpaths that limit economic and social opportunity. As the nation continues developing, communities expand these pathways (funded in part by remittances sent from overseas) into vehicular roads for better access to markets, educational opportunities, and healthcare. The resulting informal roads often create landslides by undercutting slopes, providing pathways for water to seep into potential slide planes, and producing debris that is easily mobilized during heavy rainfall (e.g. Sidle et al., 2006; Fig. 1). Access to heavy machinery (Fig. 2a) accelerates the pace of road construction, and the subsequent triggered landslides (Fig. 2b and c) disrupt the transportation networks that bring much needed goods and services to and from rural communities, damage agricultural lands in regions where subsistence farm-
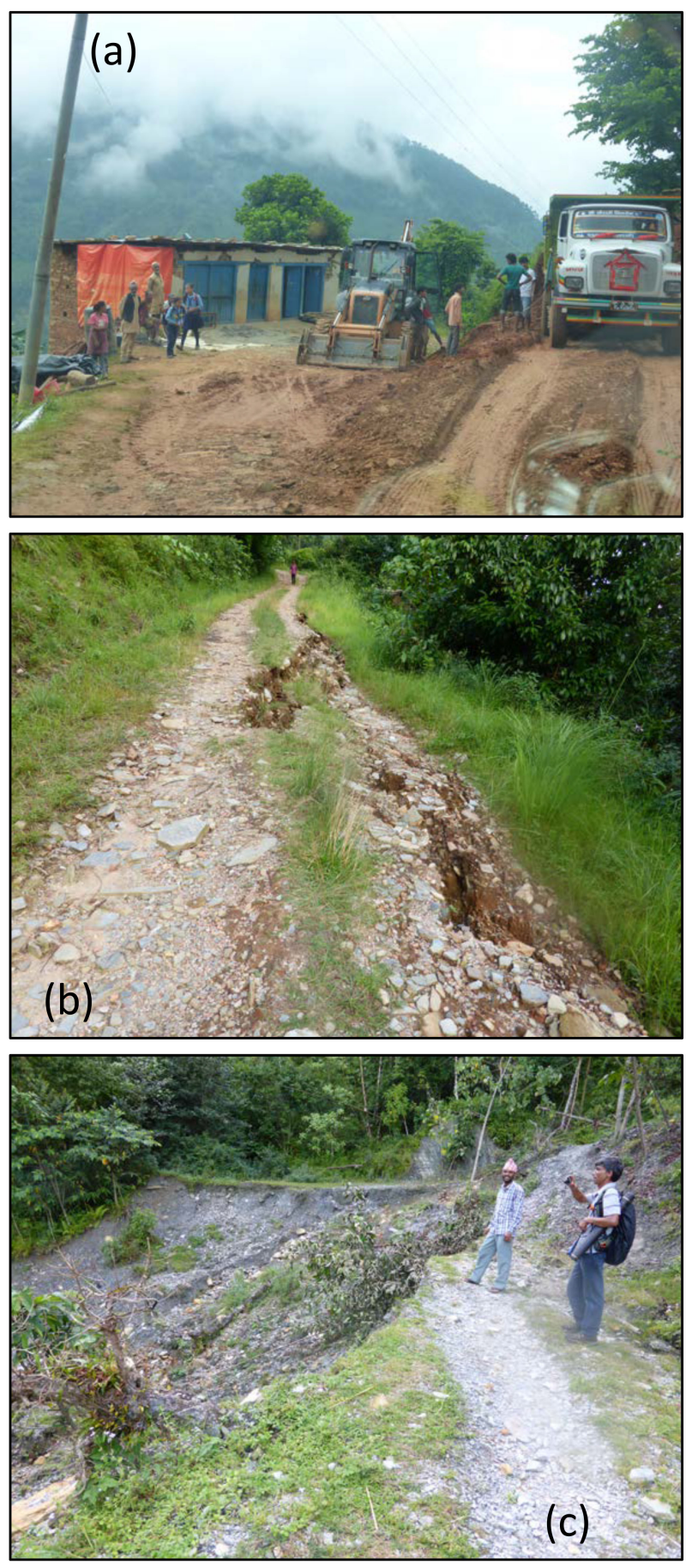

Figure 2. Informal, rural roads in Sindhupalchok District, Nepal. (a) Earth-moving equipment is hired by villagers to expand footpaths into roads that bring goods and services to isolated locations. In (b) and (c), landslides are triggered on these informally engineered rural roads. Poor drainage and lack of slope stabilizing measures facilitate failures during heavy monsoonal rains, damaging land, structures, and roads, and endangering human lives and livelihoods. Images by the authors. 

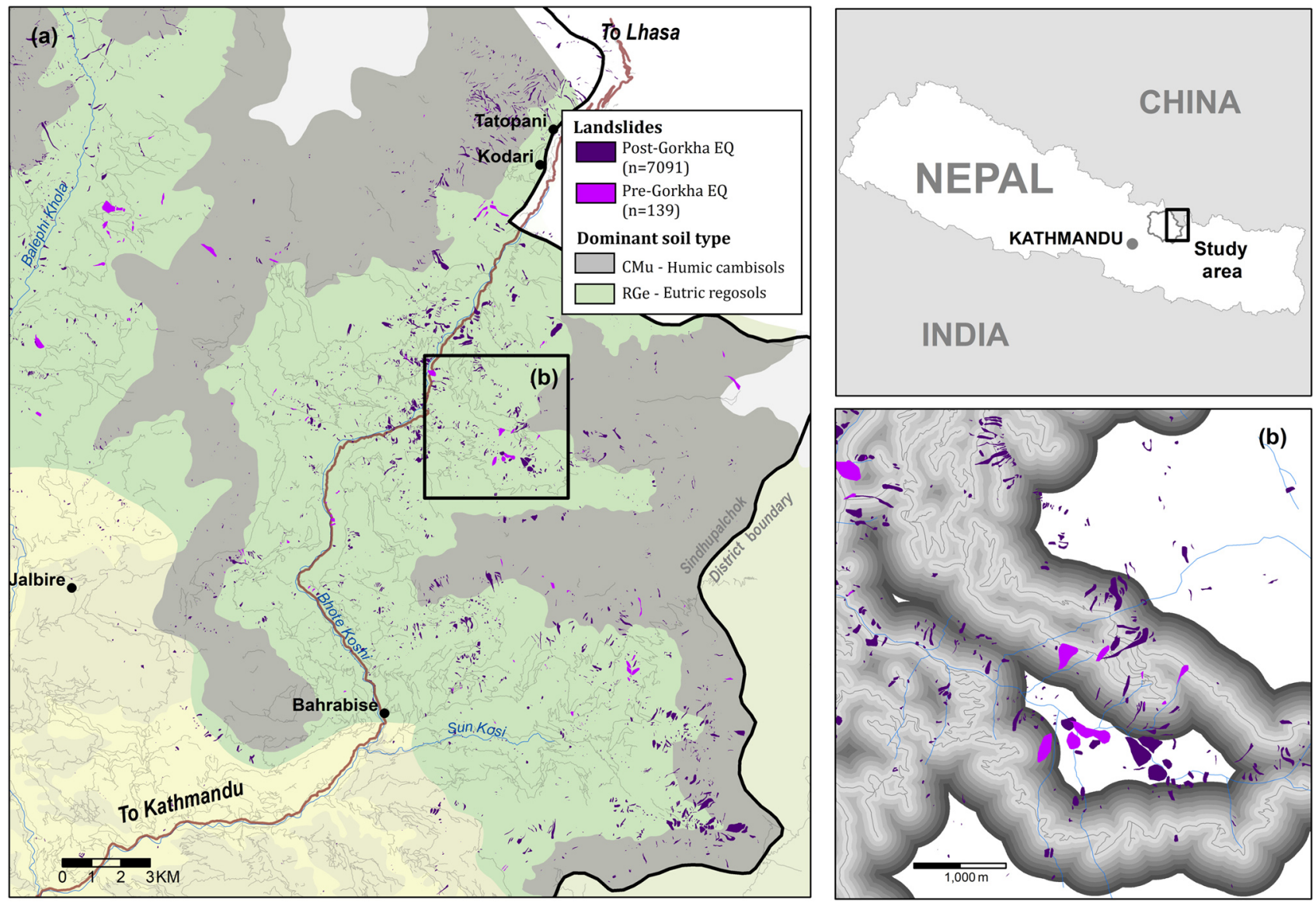

Figure 3. Roads and landslides in Sindhupalchok District, Nepal. (a) The Arniko Highway that runs between Kathmandu and Kodari at the Chinese border was heavily impacted by the 2015 Gorkha earthquake, and a dense network of informal, rural roads grows out of this main trunk road (OpenStreetMap Contributors, 2017). The dark purple polygons mark the location of landslides generated during the earthquake, and the light purple polygons were the landslides that were present before the earthquake (2014). Most landslides correspond with the RGe (Eutric Regosols) soil type as mapped by Dijkshoorn and Huting (2009). However, there is a higher percentage of earthquake-generated failures in the Humic Cambisols (CMu) soils. (b) We place buffers at $50 \mathrm{~m}$ intervals along the roads in the study area that can support a vehicle to determine the distribution of landslides that correlate spatially with the roads.

ing is the norm, and cause tens of deaths every year (DesInventar $^{1}$, 2016, Nepal Profile), all counteracting the soughtafter developmental gains.

To better understand the link between the development that will follow BRI-related development and the changes in the risk landscape, we examine the relationship between roads and landslides in the Sindhupalchok District of central Nepal (Fig. 3). The 2015 Gorkha earthquake heavily impacted Sindhupalchok, where over $95 \%$ of the houses were severely damaged and where over a third of the deaths occurred (ReliefWeb, 2017). The earthquake also generated thousands of co-seismic landslides in this district (Gnyawali and Adhikari, 2017; Fig. 3a), many of which intersect ru-

\footnotetext{
${ }^{1}$ The mortality statistics in the DesInventar database are likely a minimum, as much of their data come from media reports that originate in more accessible areas.
}

ral roads. By comparing the spatial distribution of slope failures present before and those generated during the Gorkha earthquake with a randomly distributed suite of landslides, we present compelling evidence that landslides caused by informal roads are a dangerous and often overlooked geomorphic agent that compromise the development trajectory in villages that sought to gain from the road construction. Based on these results, we show that this mode of failure should be carefully considered in studies of landslide distribution and development planning, especially as the BRI extends the road network through the Himalayas.

\section{Methods}

To help determine the significance of roads in the generation of landslides, we compare the spatial and area distribu- 
tion of landslides present before the Gorkha earthquake with those triggered by the earthquake itself. Implicit in this comparison is that the majority of landslides present before the earthquake were generated by monsoonal rains - Petley et al. (2007) show that $90 \%$ of fatal landslides occur during the rainy season (landslides that occur without fatalities likely go unreported; therefore it is possible that there are non-fatal landslides that occur throughout the year). Gnyawali and Adhikari (2017) and Roback et al. (2018) show that the primary controls on the distribution of the earthquake-generated landslides are geomorphology, degree of bedrock weathering and proximity to the earthquake rupture zone, and do not consider the effects of human alteration of the landscape. If there is a strong spatial correlation between the roads and either set of landslides, we can begin to better understand how important these roads are in altering both the physical and social landscapes.

There were on the order of 20000 landslides generated by the Gorkha earthquake (Gnyawali and Adhikari, 2017; Roback et al., 2018; Martha et al., 2016), of which we analysed 8238 in Sindhupalchok District alongside a total of 252 slides visible from satellite data in the months before the earthquake. The pre- and post-earthquake landslide inventories we used were created by manually digitizing the bare earth-landslide scars and deposits where visible in Google Earth from high-resolution satellite images (sub-metre), at an eye altitude of $500 \mathrm{~m}$, corresponding to a minimum detected landslide area being around $20 \mathrm{~m}^{2}$ (Gnyawali and Adhikari, 2017). The post-earthquake landslide inventory consists of scars and deposits observed in the image between 25 April (main-shock day) and 25 May 2015, during the dry season before the monsoon rains in June. The area and spatial distributions are similar to other catalogues of the same event (Roback et al., 2018; Martha et al., 2016; Fig. 4) where the primary controls are related to proximity to earthquake rupture zone and peak ground acceleration, as well as the physical characteristics of the topography including aspect, slope, curvature and bedrock geology. The pre-earthquake landslide inventory consists of failures identified in the area before the earthquake in images between October 2014 and February 2015 - these include slides generated during the 2014 monsoon season as well as older slides not yet covered by vegetation (Malamud et al., 2004). We ground-truthed the location and mode of failure of many of the slides visible from the Arniko Highway - the vast majority involve the regolith with very few deep-seated bedrock failures.

To better isolate the relationship between landslides and the roads, we limited our analysis to the areas in Sindhupalchok District to the agricultural regions with higher road density. The majority of landslides ( 7230 or $85 \%$ of the combined pre- and post-earthquake inventories yielding a landslide density of 6.2 slides $\mathrm{km}^{-2}$ compared to 0.5 slides $\mathrm{km}^{-2}$ in the less productive, higher elevation soils) occur in two soil types - the better developed, agriculturally productive Eutric Regosols (RGe), and the less-productive Humic Cam-
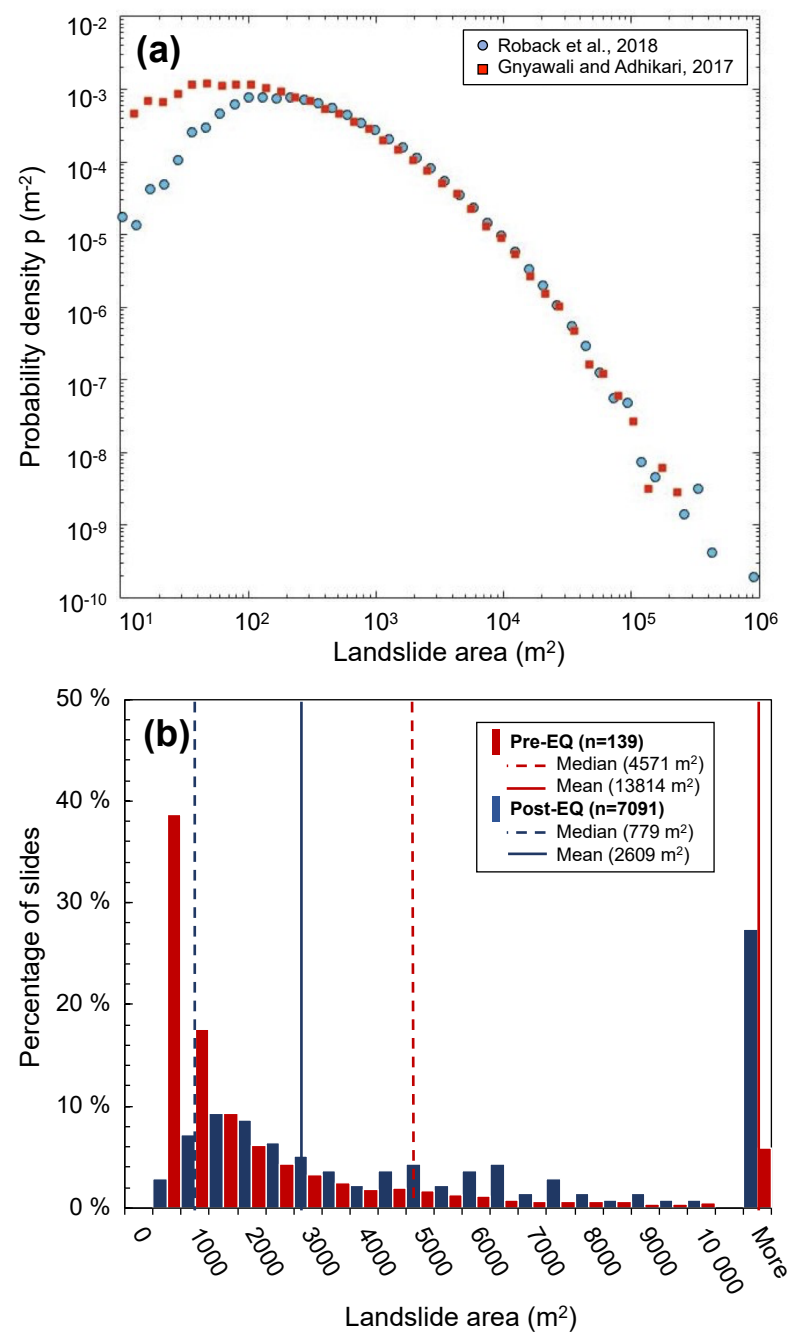

Figure 4. (a) Probability density-landslide area statistics of the Gorkha earthquake triggered landslide inventory used in this study compared to the inventory generated by Roback et al. (2018). The two curves diverge at slides with areas less than around $200 \mathrm{~m}^{2}$ suggesting that the Gnyawali and Adhikari (2017) data selected more smaller slides. (b) Histograms of normalized areas of landslides present before and after the 2015 Gorkha earthquake. The higher mean and median values for the monsoon-generated landslides as compared to the earthquake-generated landslides may likely reflect missed smaller, older landslides that were covered by vegetation (Malamud et al., 2004).

bisols $(\mathrm{CMu})$ that occur in higher, more arid zones (Dijkshoorn and Huting, 2009; Fig. 3a). Of the 7091 earthquaketriggered landslides in these two soil types, only 2687 , or $38 \%$ are in $\mathrm{CMu}$ (which covers $629 \mathrm{~km}^{2}$ in this district with a landslide density of 4.3 slides $\mathrm{km}^{-2}$ ), and 35 of 139 $\left(25 \%\right.$, and 0.06 slides $\mathrm{km}^{-2}$ ) pre-earthquake landslides occur in this soil type. The remaining 104 monsoon-triggered landslides are in an area with more agricultural development in the RGe unit $\left(530 \mathrm{~km}^{2}\right.$ in this district with a density of 
0.2 slides $\mathrm{km}^{-2}$ ), and hence more exposed communities and roads.

As the earthquake occurred near the end of the dry season, we expect the failures to be less affected by the presence of water, and slide location would be less influenced by features such as roads that concentrate water. Conversely, if as we expect there is a higher proportion of pre-earthquake landslides near roads, it is likely that the oversteepening and poor drainage of informal roads is indeed adding to the hazard.

To better assess the causal relationship that has been documented by many studies (e.g. Petley et al., 2007; Sidle and Ziegler, 2012; Froude and Petley, 2018), we use a Geographic Information System (GIS) to measure the proximity of pre- and post-earthquake slides to the roads. Using the existing road network (OpenStreetMap Contributors, 2017), we filtered out the smallest trails and footpaths, leaving only tracks that had been improved and could likely support a vehicle (assessment based on field observations). We then generated nine $50 \mathrm{~m}$ buffers perpendicular to these roads (total of $450 \mathrm{~m}$ on each side) and tabulated the number of landslides (scar and/or deposits) that intersected a buffer at the particular distance from the road (Fig. 3b).

In addition, we generated 20 sets of randomized landslides (10 pre-earthquake, 10 post-earthquake) based on the distribution landslide areas to better determine if there is a spatial relationship of roads and failures. For both the measured preand post-earthquake slides, we plotted the cumulative lognormal area distribution, then fit a power-law curve that we used to generate the random slide set. For the pre-earthquake slides $(n=139)$, the areas $\left(A_{\text {pre-EQ }}\right)$ were calculated using sets of random numbers $(x)$ :

$A_{\text {pre-EQ }}=0.35 x^{0.097} ; S=0.05 \mathrm{~m}^{2}$,

and for the slides generated by the earthquake $(n=7092)$, the areas are $\left(A_{\text {post-EQ }}\right)$

$A_{\text {post-EQ }}=0.44 x^{0.089} ; S=0.04 \mathrm{~m}^{2}$.

For each of the 20 sets of randomly generated slides, we placed them randomly within the $\mathrm{CMu}$ and $\mathrm{RGe}$ soil types in Sindhupalchok District measuring the distances from the roads in each of 10 separate runs. While these data lack the complex shapes of the actual landslides (they are modelled as circular), we believe they represent a reasonable approximation of a random distribution of failures across the landscape.

\section{Results}

Observations from the field and numerous previous studies suggest a strong spatial correlation between roads and landslides (e.g. Laban, 1979; Sidle et al., 2006; Petley et al., 2007; Froude and Petley, 2018), and others on how landslides affect roads (e.g. Irigaray et al., 2000). However, there have been few studies that seek to quantify the relationship with the aim of moving past correlation to causation. Using satellite data, we find that the majority of landslides in Sindhupalchok District occur in the soil types that support agriculture - the Eutric Regosols and, to a lesser extent, the $\mathrm{Hu}$ mic Cambisols. Amongst the landslides that were present before the 2015 earthquake, we observe a strong signal that demonstrates the genetic relationship between agrarian development, roads, and landslides.

Although the number of monsoon-triggered landslides is small by comparison with the earthquake-generated inventory - the total area of landslides is $1.9 \mathrm{~km}^{2}\left(1.2 \mathrm{~km}^{2}\right.$ in $\mathrm{RGe}$ and $0.7 \mathrm{~km}^{2}$ in $\mathrm{CMu}$ ), whereas the earthquake-triggered slides cover $18.4 \mathrm{~km}^{2}\left(9.8 \mathrm{~km}^{2}\right.$ in $\mathrm{RGe}$ and $8.6 \mathrm{~km}^{2}$ in $\left.\mathrm{CMu}\right)$. However, it is possible that many of the smaller rainfallinduced slides may been covered by vegetation (Malamud et al., 2004). In the soil types that support agriculture, $45 \%$ (63) of the 139 pre-earthquake landslides occur within $100 \mathrm{~m}$ of a road, whereas only $21 \%$ (1490) of the 7091 landslides generated by the earthquake are within $100 \mathrm{~m}$ of a road. Of the randomly generated landslides, between $21 \%$ (of the post-earthquakes slide area distribution) and 26\% (of the pre-earthquake slides) of the failures are within $100 \mathrm{~m}$ of a road, closely matching the spatial distribution of the earthquake landslides (Fig. 5). Stated differently, there are twice as many monsoon-generated landslides near roads as earthquake-generated landslides, and twice as many as in a randomly located suite of slides with the same area distribution.

The shape of the curve that shows the cumulative number of landslides at increasing distances from the roads in Fig. 5 holds some additional information. If there is a causative relationship between roads and landslides, we might expect to see a change in slope of the cumulative number of slides with increasing distances from the road that would correspond to a critical distance where the mechanical influence of the road disturbance is reduced, and the number of landslides begins to decrease (e.g. Brown, 1987). However, we do not observe this change in slope of the data, possibly due to resolution issues of the smaller slides. The trend is not linear - if we had a random distribution of roads across the landscape in addition to the randomly distributed landslides, we would expect to see a linear increase in the cumulative number of landslides with distance from the road. What we notice instead is that there are fewer slides further away from the roads than would be expected, suggesting that the roads might be in locations that are predisposed to failure, such as near valley bottoms or ridge tops.

\section{Discussion}

Informal rural roads are causing dramatic changes in the physical and social landscapes of the Middle Hills region of Nepal. Although the number of slides generated by monsoon rains during a given year is small when compared to the vast 


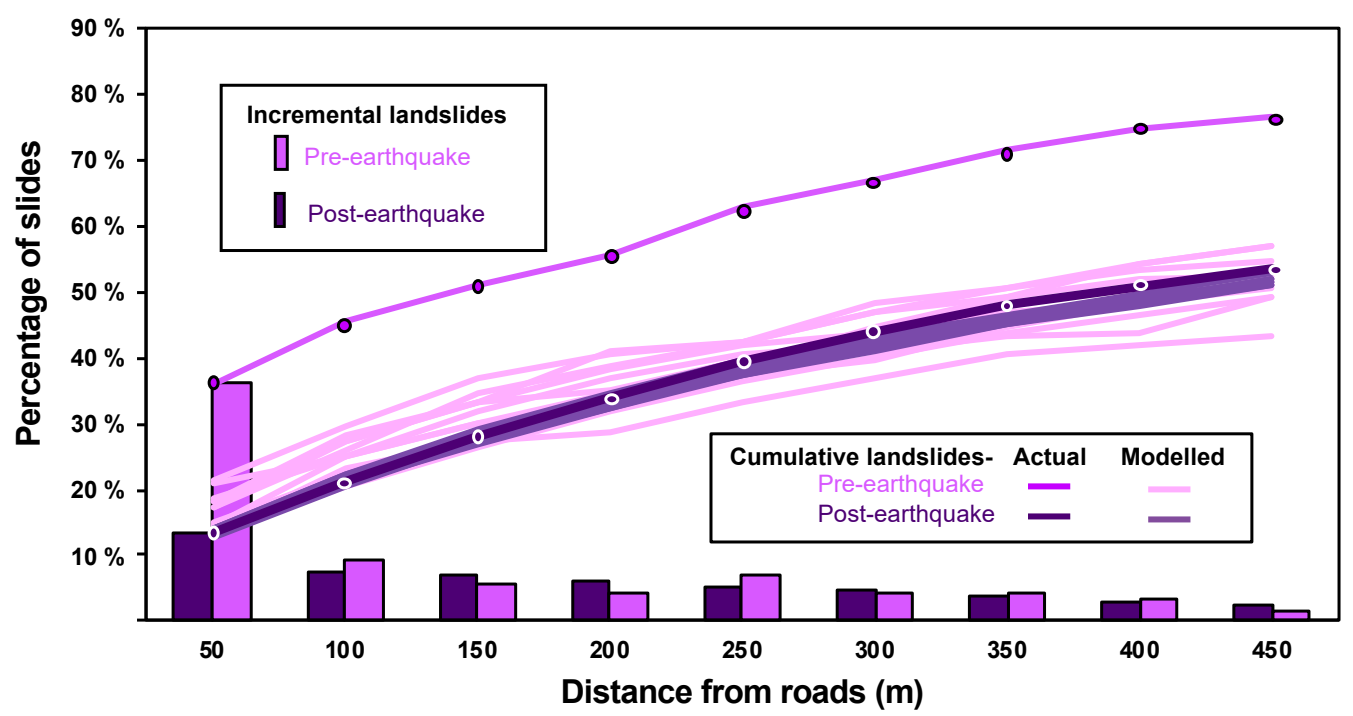

Figure 5. Distance from roads of earthquake, monsoon and randomly generated landslides. The light and dark purple bars are the incremental percentage of pre- and post-earthquake landslides, respectively, that occur at a given distance from a road. The light and dark purple lines are the cumulative percentage of slides that occur at the given distances from the road; the spread of the cumulative number of the modelled ( $n=10$ runs). Randomly located landslides within the different buffer distances are shown in lighter shades of the respective purple colours.

number of slides triggered by the Gorkha earthquake, they nonetheless have a substantial impact on the physical and social landscape. This study shows that there are twice as many landslides in the more developed areas (with its good agricultural soils and vast network of informal roads) as there would presumably be if the roads were better engineered. The productive soils lead to more agriculture, and agriculture benefits by having access to markets by way of roads. As the population in this region will be impacted by the proposed BRI trunk road, expansion of the informal, rural transportation network is likely to follow, triggering more monsoonrain-driven failures, property loss, transportation disruptions, and deaths.

The relationship between roads and landslides gives us an idea of how important these anthropogenically controlled slides are in shaping the landscape. The risk of roadside failures is heightened during the monsoonal rains because of slope oversteepening on the uphill side of the road and the deposition of excavated debris on the downhill side that is easily mobilized during heavy rainfall events (accentuated by runoff from the road - see Sidle et al., 2006). To make a stronger link to causation, it would be helpful to model how far the changes associated with the road influence the failure mechanics. Regardless, this combined road-rainfall effect is more acute than earthquake-generated failures in terms of percentage, if not total numbers.

These road-related failures also impact the sediment delivery system. While this snapshot of monsoon-induced slides caused by informal roads is small compared to those generated by the earthquake, it is important to consider this addi- tional material in annual budget calculations based on current river sediment load, and over longer periods of time. There are many new hydropower schemes following the BRI trunk road development, and they will be forced to contend with this additional sediment burden.

China's BRI fits well with the Nepali government's long-term development strategy to promote road development (Murton, 2016; Economist, 2017). While the roads constructed by the Chinese in the Himalayas are wellengineered, informal and less well-engineered roads funded by direct foreign investment and remittances have expanded significantly since the end of the Maoist insurgency in 2006 (MoF, 2016). With the costs of rural roads managed by federally funded districts, scarce funds needed for road maintenance compete with the need for investment in other sectors. Leibundgut et al. (2016) found that the economic impact of rural roads around Phewa Lake, Kaski District of western Nepal, amounted to USD 117287 per year in maintenance costs, forecasted to rise to USD 192000 per year by 2030 with the current rate of road construction. Furthermore, over the last 30 years, tens to hundreds of deaths due to landslides are recorded every year (Petley et al., 2007; DesInventar, 2016), and yet it remains unclear how many of these failures are related to roads. Considerations of safer and more sustainable "green roads" that consider local engineering geology and best practices in design, construction and maintenance (Hearn and Shakya, 2017) are outweighed by local communities negotiating with limited funds, short-term political agendas and ease of access to heavy equipment. 


\section{Conclusions}

The landslides generated by the 2015 Gorkha earthquake provide an opportunity to compare the distribution of earthquake-triggered, "natural" failures with those triggered by humans in a landscape heavily modified by informal road construction. By comparing earthquake-generated failures and those caused by monsoonal rains before the earthquake with suites of randomly located landslides, we show that there are likely to be twice as many monsoon-generated landslides in terrain with poorly constructed roads as would be present without roads. While these anthropogenic slides do not represent much of a change in the physical systems during any given year, over time, their impact cannot be ignored. The socio-economic landscape, however, is being severely impacted by an explosion of informal roads to the point that it is hindering the socioeconomic development that the roads sought to bring and killing too many people in the process. Landslides in the Anthropocene are no longer simply a function of seismology, geology, geomorphology and climate as poorly built roads are rapidly changing the landscape.

Better engineered roads will lead to more sustainable economic development, but these roads come with a price. Although foreign investment aids construction, maintenance costs fall on impoverished communities who must decide between access and basic services. Green solutions such as plantings on metastable hillslopes are more economically sustainable and can be implemented by community members with minimal training. There is little that can be done to control the tectonics or the climate, but economically feasible and environmentally sound adaptations will reduce losses in resources and lives.

Data availability. The raw data required in this study are available at https://doi.org/10.25540/svdq-k443 (Kaushal et al., 2018).

Author contributions. The project was conceptualized by SJ, PLR, KSR and BGM during several field seasons. KGR and BRA curated the landslide database along with field observations. BGM and MQ conceptualized and completed the formal analysis of the GIS analysis. The original draft was written by BGM and subsequently reviewed and edited by all co-authors.

Competing interests. The authors declare that they have no conflict of interest.

Special issue statement. This article is part of the special issue "Landslide-road network interactions". It is not associated with a conference.
Acknowledgements. The authors would like to thank Yale-NUS College for supporting field research in Nepal. Special thanks go to our colleagues Aaron Pang, Stephanie Chee, Adolfo Dominguez, and the students from the Yale-NUS College Learning Across Boundaries Nepal programme. Thanks also to Cees van Westen and Marie Delalay for constructive ideas in the field, Zhana Sandeva and Kuman Gurung for logistics, Jan Gruber for the modelling ideas, and Rohan Mukherjee (YNC) for geopolitical framing.

Edited by: Faith Taylor

Reviewed by: two anonymous referees

\section{References}

BBC - British Broadcasting Corporation: Landslides triggered by rain kill at least 29 , available at: http://www.bbc.com/news/ world-asia-33714147 (last access: 21 November 2018), 2015.

Bhandary, N. P., Yatabe, R., Dahal, R. K., Hasegawa, S. and Inagaki, H.: Areal distribution of large-scale landslides along highway corridors in central Nepal, Georisk: Assess. Manage. Risk Eng. Syst. Geohaz., 7, 1-20, 2013.

Bharti, V., Singh, C., Ettema, J., and Turkington, T. A. R.: Spatiotemporal characteristics of extreme rainfall events over the Northwest Himalaya using satellite data, Int. J. Climatol., 36, 3949-3962, 2016.

Bhushal, R.: One Belt, One Road Fuels Nepal's Dreams, The Wire (India), available at: https://thewire.in/156554/ nepal-china-obor-transport-infrastructure (last access: 21 November 2018), 2017.

Brown, S. R.: A note on the description of surface roughness using fractal dimension, Geophys. Res. Lett., 14, 1095-1098, 1987.

DesInventar Disaster information management system, Profile - Nepal, available at: http://www.desinventar.net/DesInventar/ profiletab.jsp?countrycode=npl, last access: 13 December 2016.

Dijkshoorn, J. A. and Huting, J. R. M.: Soil and terrain database for Nepal, Report 2009/01, ISRIC - World Soil Information, Wageningen, the Netherlands, available at: https://www. isric.org/projects/soil-and-terrain-soter-database-programme (12 November 2018), 2009.

DoR - Department of Roads: National Transportation Policy Ministry of Physical Planning and Works, 2058 (2001/2002), Kathmandu, 15 pp., available at: http://dor.gov.np/home/ circular/force/national-207transport-policy-2058 (last access: 12 November 2018), 2002.

DoR - Department of Roads: Road Network Data, Government of Nepal, Department of Roads, DoR, Kathmandu, 17 pp., available at: http://www.dor.gov.np/home, 19 November 2017.

Economist, India faces growing competition with China in its own backyard, available at: https://www.economist.com/asia/2017/12/19/ india-faces-growing-competition-with-china-in-its-own-backyard, last access: 19 December 2017.

Froude, M. J. and Petley, D. N.: Global fatal landslide occurrence from 2004 to 2016, Nat. Hazards Earth Syst. Sci., 18, 2161-2181, https://doi.org/10.5194/nhess-18-2161-2018, 2018.

Gnyawali, K. R. and Adhikari, B.: Spatial Relations of the Earthquake Induced Landslides Triggered by 2015 Gorkha Earthquake $M_{\mathrm{W}}=7.8$, in: Advancing Culture of Living with Landslides, 
WLF 2017, edited by: Mikos, M., Casagli, N., Yin, Y., and Sassa, K., Springer, Cham, 2017.

Hearn, G. J. and Shakya, N. M.: Engineering challenges for sustainable road access in the Himalayas, Q. J. Eng. Geol. Hydrogeol., 50, 69-80, 2017.

Irigaray, C., Lamas, F., El Hamdouni, R., Fernandez, T., and Chacon, J.: The Importance of the Precipitation and the Susceptibility of the Slopes for the Triggering of Landslides Along the Roads, Nat. Hazards, 21, 65-81, 2000.

Kaushal, R. G., Basanta, R. A., and McAdoo, B. G.: Landslides in Sindhupalchok District, Nepal before and after the 2015 Gorkha Earthquake, ScholarBank@NUS Repository, Dataset, https://doi.org/10.25540/svdq-k443, 23 November 2018.

Laban, P.: Landslide Occurrence in Nepal, Food and Agriculture Organisation, Food and Agriculture Organisation, Government of Nepal, Ministry of Forest, Soil and Water Conservation, UNDP, Kathmandu, p. 30, 1979.

Leibundgut, G., Sudmeier-Rieux, K., Devkota, S., Jaboyedoff, M., Derron, M.-H., Penna, I., and Nguyen, L.: Rural earthen roads impact assessment in Phewa watershed, Western region, Nepal, Geoenvironm. Disast., 3, https://doi.org/10.1186/s40677016-0047-8, 2016.

Malamud, B. D., Turcotte, D. L., Guzzetti, F., and Reichenbach, P.: Landslide inventories and their statistical properties, Earth Surf. Proc. Land., 29, 687-711, 2004.

Martha, T. R., Roy, P., Mazumdar, R., Govindharaj, K. B., and Kumar, K. V.: Spatial characteristics of landslides triggered by the $2015 M_{\mathrm{W}} 7.8$ (Gorkha) and $M_{\mathrm{W}} 7.3$ (Dolakha) earthquakes in Nepal, Landslides, 14, 697-704, 2016.
MoF - Ministry of Finance, Government of Nepal, Economic Surveys 2001-2015, availalbe at: http://www.mof.gov. np/en/archive-documents/economic-survey-21.html, last access: 29 November 2016.

Murton, G.: A Himalayan Border Trilogy: The Political Economies of Transport Infrastructure and Disaster Relief between China and Nepal, Cross-Currents: East Asian History and Culture Review, E-Journal No.18, available at: https://cross-currents.berkeley.edu/e-journal/issue-18 (last access: 21 November 2018), 2016.

Open Street Map Contributors: https://planet.openstreetmap.org/, last access: 17 December 2017.

Petley, D., Hearn, G. J., Hart, A., Rosser, N., Dunning, S., Oven, K., and Mitchell, W.: Trends in landslide occurrence in Nepal, Nat. Hazards, 43, 23-44, 2007.

ReliefWeb: Nepal Earthquake, District Profile - Sidhupalchok 08.05.2015, available at: https://reliefweb.int/report/nepal/ nepal-earthquake-district-profile-sindhupalchok-08052015, last access: 12 December 2017.

Roback, K., Clark, M. K., West, A. J., Zekkos, D., Li, G., Gallen, S. F., Chamlagaine, D., and Godt, J. W.: The size, distribution, and mobility of landslides caused by the $2015 M_{\mathrm{W}} 7.8$ Gorkha earthquake, Nepal, Geomorphology, 301, 121-138, 2018.

Sidle, R. and Ziegler, A.: The dilemma of mountain roads, Nat. Geosci., 5, 437-438, 2012.

Sidle, R., Ziegler, A., Negishi, J., Nik, A., Siew, R., and Turkelboom, F.: Erosion processes in steep terrain- Truths, myths, and uncertainties related to forest management in Southeast Asia, Forest Ecol. Manage., 224, 199-225, 2006. 